Anna Rzucidlo-Hymczak ${ }^{1}$, Hubert Hymczak², Dariusz Plicner ${ }^{3}$, Aldona Olechowska-Jarząb ${ }^{4}$, Anna Gorczyca ${ }^{1}$, Jarosław Stoliński ${ }^{3}$.

\title{
EPIDEMIOLOGIC CHARACTERISTICS AND CLINICAL COURSE OF CHILDREN WITH ACUTE GASTROENTERITIS HOSPITALIZED IN THE DEPARTMENT OF PEDIATRIC INFECTIOUS DISEASES AND HEPATOLOGY AT JOHN PAUL II HOSPITAL IN KRAKOW
}

\author{
ANALIZA PRZEBIEGU I OCENA EPIDEMIOLOGICZNA OSTRYCH ZAKAŻEŃ \\ PRZEWODU POKARMOWEGO U DZIECI HOSPITALIZOWANYCH W ODDZIALE \\ CHORÓB INFEKCYJNYCH DZIECI I HEPATOLOGII DZIECIĘCEJ KRAKOWSKIEGO \\ SZPITALA SPECJALISTYCZNEGO IM. JANA PAWŁA II
}

'Oddział Chorób Infekcyjnych Dzieci i Hepatologii Dziecięcej, KSS im. Jana Pawła II, Kraków ${ }^{2}$ Oddział Anestezjologii i Intensywnej Terapii, KSS im. Jana Pawła II, Kraków,

${ }^{3}$ Oddział Kliniczny Chirurgii Serca, Naczyń i Transplantologii CM UJ, KSS im. Jana Pawła II, Kraków ${ }^{4}$ Ośrodek Nowoczesnej Diagnostyki Laboratoryjnej, Pracownia Mikrobiologii, KSS im. Jana Pawła II, Kraków

\section{ABSTRACT}

INTRODUCTION. Acute gastroenteritis (AGE) is considered one of the most common reasons for hospitalization and the third leading cause of death related to infectious diseases in children. The incidence and prevalence of campylobacteriosis is lower in Poland than in other parts of the European Union.

THE AIM OF THE STUDY. The aim of the study was to investigate the epidemiology and clinical features of AGE in hospitalized children.

MATERIALS AND METHODS. The study population comprised 462 consecutive patients with AGE, hospitalized in the Department of Pediatric Infectious Diseases and Hepatology at John Paul II Hospital in Krakow during 2016. After admission in the hospital, the patients' stool samples were collected and tested for viral or bacterial pathogens. The specimens were analyzed using classical cultural methods and qualitative immunochromatographic assays for pathogens screening. The patients' age, sex, etiological factor, seasonal distribution, hospital length of stay and symptoms of disease were collected retrospectively.

RESULTS. The median age of AGE patients was 3.0 years [1.5-5.5]. Eighty percent of all AGE cases occurred in patients under 5 years of age $(\mathrm{p}<0.001)$. Rotavirus was the leading cause of AGE and Campylobacter was the most common bacterial pathogen ( $\mathrm{p}=0.001, \mathrm{p}=0.05$ respectively). The average length of hospital stay was $3.1 \pm 1.6$ days. The longest hospitalization stays were related to patients with enteropathogenic Escherichia coli and Salmonella $(p<0.001$ for all). A seasonal pattern was observed for etiological factors of AGE $(p<0.001)$. Fever, diarrhea and pathological stool contaminations occurred more frequently in patients with bacterial AGE ( $p<0.001$ for all).

SUMMARY AND CONCLUSIONS. This study showed that routine diagnosis of Campylobacter in all children with AGE is associated with a higher than reported prevalence of campylobacteriosis.

Key words: acute gastroenteritis, epidemiology, Campylobacter

\section{STRESZCZENIE}

WSTĘP. Ostre zakażenie przewodu pokarmowego (AGE) to jedna z najczęstszych przyczyn hospitalizacji oraz trzecia przyczyna śmierci dzieci z powodu chorób zakaźnych. Zapadalność na kampylobakteriozę w Polsce jest mniejsza w porównaniu do całej Unii Europejskiej.

CEL PRACY. Analiza przebiegu i ocena epidemologiczna AGE u dzieci hospitalizowanych w naszym oddziale. MATERIAL I METODY. Badaniem objęto 462 kolejnych pacjentów hospitalizowanych w 2016 roku w Oddziale Chorób Infekcyjnych Dzieci i Hepatologii Dziecięcej, Krakowskiego Szpitala Specjalistycznego

(C) National Institute of Public Health - National Institute of Hygiene / Narodowy Instytut Zdrowia Publicznego - Państwowy Zakład Higieny 
im. Jana Pawła II, u których rozpoznano AGE. U każdego pacjenta zgłaszającego się z objawami AGE badano kał w kierunku infekcji wirusowej i bakteryjnej. Materiał poddano analizie mikrobiologicznej wykorzystując do diagnostyki klasyczną metodę posiewu mikrobiologicznego stolca oraz screening, oparty o jakościowe testy immunochromatograficzne. W badaniu retrospektywnym analizowano wiek, płeć, czynnik etiologiczny AGE, sezonowość zachorowania, długość hospitalizacji oraz objawy chorobowe.

WYNIKI. Mediana wieku chorych wynosiła 3,0 roku [1,5-5,5]. 80\% wszystkich przypadków AGE wystąpiło u dzieci $<5$ r.ż. $(p<0,001)$. Najczęstszym czynnikiem etiologicznym AGE był rotawirus $(\mathrm{p}=0,001)$. Natomiast spośród czynników bakteryjnych dominowały zakażenia wywołane przez pałeczki Campylobacter $(\mathrm{p}=0,05)$. Srednia długość hospitalizacji wynosiła 3,1 $\pm 1,6$ doby. Najdłuższego pobytu w szpitalu wymagali chorzy, u których przyczyną AGE była enteropatogenna Escherichia coli i Salmonella (dla obu p $<0,001$ ). Zaobserwowano zależność pomiędzy czynnikiem etiologicznym a kwartałem wystąpienia zachorowania $(p<0,001)$. Gorączka, biegunka oraz patologiczne domieszki w kale dominowały u pacjentów z bakteryjną etiologią AGE (dla wszystkich $\mathrm{p}<0,001$ ).

WNIOSKI. Rutynowe wykonywanie diagnostyki w kierunku zakażenia pałeczkami Campylobacter u wszystkich dzieci z AGE pozwala przypuszczać występowanie większej liczby zachorowań na kampylobakteriozę niż aktualnie rejestrowana.

Słowa kluczowe: ostre zakażenie przewodu pokarmowego, epidemiologia, Campylobacter

\section{INTRODUCTION}

Acute gastroenteritis (AGE) in children is considered one of the most common causes of admission to health centers, one of the most frequent reason of hospitalization and the third leading cause of death related to infectious diseases worldwide $(1,2)$. Only about $20 \%$ of AGE are caused by bacteria and the other cases have mainly viral etiology (3).

Rotavirus is the leading cause of AGE in infants and young children and the major contributor to hospitalization for diarrhea in countries that have no rotavirus vaccines in their national immunization schedules $(3,4,5)$. With the continuing decline in cases of rotavirus-associated AGE, since the implementation of routine childhood vaccination against rotavirus, norovirus infection has become the most common cause of medically treated AGE $(6,7)$. However, rotavirus is still responsible for most cases of AGE and overall childhood mortality from diarrhea. In 2013, rotavirus mortality was estimated at 215,000 deaths among children younger than 5 years of age, a decline from 453,000 rotavirus deaths in $2008(2,8)$. Rotavirus disease constitutes a large public health burden in the European Union (EU). It is estimated that 3.6 million episodes of rotavirus disease occur annually among children younger than 5 years of age. Every year in Europe, rotavirus accounts for 231 deaths, almost 700,000 outpatient visits and more than 87,000 hospitalizations (9).

Campylobacter is the most commonly reported AGE bacterial pathogen in the EU and worldwide $(10,11,12)$. In Poland the number of reported confirmed cases of campylobacteriosis has increased over the last years $(13,14)$. Nevertheless, routine diagnosis of Campylobacter species is only performed in a few laboratories in Poland. This lack of diagnosis is most likely the reason the incidence and prevalence of campylobacteriosis is lower in Poland than in other parts of the EU (1.69 vs 71 per

\section{WSTEP}

Ostre zakażenie przewodu pokarmowego (acute gastroenteritis-AGE) to częsty powód konsultacji dziecka w podstawowej opiece zdrowotnej, jedna z najczęstszych przyczyn hospitalizacji dzieci na oddziałach pediatrycznych i zakaźnych oraz trzecia najczęstsza przyczyna śmierci z powodu chorób zakaźnych na całym świecie $(1,2)$ Szacuje się, że tylko $20 \%$ AGE spowodowana jest przez czynniki bakteryjne, a znaczna większość wywołana jest przez wirusy (3).

W krajach niemających w obowiązku szczepień przeciwko rotawirusom, wirus ten jest najczęstszą przyczyną AGE u niemowląt i małych dzieci oraz głównym powodem hospitalizacji dzieci z biegunką $(3,4,5)$. W państwach, gdzie szczepienia przeciwko rotawirusom zostały włączone do narodowego programu szczepień, zaobserwowano zmniejszenie liczby hospitalizacji dzieci z powodu infekcji rotawirusowej oraz znaczne zwiększenie udziału norowirusa w etiologii AGE $(6,7)$. Niemiej jednak rotawirus nadal odpowiada za znaczną większość zachorowań oraz znaczny odsetek zgonów dziecięcych na całym świecie. Według globalnych szacunków liczba zgonów wywołana przez rotawirusy w populacji dzieci poniżej 5 r.ż. w 2013 roku wyniosła 215 000. Liczba ta zmniejszyła się z 453000 w 2008 roku $(2,8)$. Infekcja rotawirusowa stanowi duże obciążenie dla zdrowia publicznego w krajach Unii Europejskiej (UE). Szacuje się, że w UE u dzieci poniżej 5 r.ż. występuje rocznie 3,6 miliona epizodów choroby rotawirusowej, co powoduje rocznie około 700000 wizyt ambulatoryjnych i 87000 hospitalizacji (9).

Wśród czynników bakteryjnych wywołujących AGE zarówno w krajach UE, jak i na całym świecie najczęstsze są zakażenia wywołane pałeczkami Campylobacter $(10,11,12)$. W Polsce w ostatnich latach liczba rejestrowanych zachorowań na kampylobakteriozę wykazuje stale trend wzrostowy $(13,14)$. Pomimo tego, 
100,000 population in 2014) $(10,12,14)$. According to the National Institute of Public Health-National Institute of Hygiene, Salmonella is the most common bacterial cause of AGE in Poland (787 cases of campylobacteriosis vs 9701 cases of salmonellosis in 2016) (14).

Routine diagnosis of Campylobacter in all children with AGE is performed in the Department of Pediatric Infectious Diseases and Hepatology at John Paul II Hospital in Krakow.

\section{THE AIM OF THE STUDY}

The aim of the current study was to investigate the epidemiology and clinical features of AGE in hospitalized children. We assessed the type of pathogens (viral, bacterial, parasitic, mixed or indefinite) and we sought to investigate the links between the etiological factor and the clinical course. We hypothesized that routine diagnosis of Campylobacter in all children with AGE is associated with a higher than reported prevalence of campylobacteriosis.

\section{MATERIALS AND METHODS}

Patients. The study was performed in accordance with the Declaration of Helsinki. 1435 children were hospitalized in the Department of Pediatric Infectious Diseases and Hepatology at John Paul II Hospital in Krakow in 2016. The study population comprised 462 consecutive patients with AGE. AGE was defined as the sudden onset of diarrhea (loose or watery stool, with or without blood, pus or mucus, more than 3 times per day) and/or vomiting with or without fever. Exclusion criteria were any signs of illness that persisted more than two weeks (classified as persistent or chronic gastroenteritis).

The patients' age, sex, etiological factor, seasonal distribution, hospital length of stay and symptoms of disease (fever, vomiting and diarrhea with or without presence of blood, mucus and/or pus) were collected retrospectively. Stool samples were examined after admission to the hospital for rotavirus, norovirus, adenovirus, Campylobacter, Salmonella and Yersinia enterocolitica. Also, in children under 2 years of age, the stool was studied for enteropathogenic Escherichia coli (EPEC). In case of indefinite pathogens and persistent diarrhea, the specimen was checked for parasitic infection (Giardia lamblia, Entamoeba, Cryptosporydium). In children with risk factors (long-term antibiotic therapy, previous hospitalization), stool samples were examined for toxigenic strains of Clostridium difficile. An analysis to detect verotoxin-producing Escherichia coli. eg $\mathrm{O}: 157: \mathrm{H} 7$ was not performed.

Microbiological analysis. Stool specimens (liquid or semi liquid) were analyzed using classical cultural methods and qualitative immunochromatographic assays for pathogens screening. diagnostyka w kierunku zakażeń pałeczkami Campylobacter nadal prowadzona jest rutynowo jedynie w kil$\mathrm{ku}$ ośrodkach na terenie kraju. Prawdopodobnie $\mathrm{z}$ tego powodu zapadalność na kampylobakteriozę w Polsce odbiega od średniej rejestrowanej w całej UE (1,69 vs 71 na 100 tys. w 2014 roku) $(10,12,14)$. Wg raportów Narodowego Instytutu Zdrowia Publicznego - Państwowego Zakładu Higieny, w Polsce nadal dominują, wśród bakteryjnych przyczyn AGE, infekcje wywołane pałeczkami Salmonella (w 2016 roku stwierdzono 787 przypadków Campylobacter vs 9701 zakażeń pokarmowych wywołanych przez Salmonella) (14).

Oddział Chorób Infekcyjnych Dzieci i Hepatologii Dziecięcej Krakowskiego Szpitala Specjalistycznego im. J. Pawła II jest ośrodkiem wykonującym rutynowo diagnostykę w kierunku zakażeń pałeczkami Campylobacter u dzieci zgłaszających się z objawami AGE.

\section{CEL PRACY}

Celem przedstawionego badania była ocena przebiegu i analiza epidemiologiczna AGE u dzieci, hospitalizowanych w naszym oddziale. W tym celu ocenialiśmy czynnik etiologiczny AGE (wirusowy, bakteryjny, pasożytniczy, mieszany, nieokreślony) oraz analizowaliśmy przebieg kliniczny zakażeń w zależności od przyczyn choroby. W badaniu postawiliśmy hipotezę, że rutynowe wykonywanie testów na Campylobacter u wszystkich dzieci z AGE wykaże większą liczbę zachorowań niż aktualnie rejestrowana.

\section{MATERIAŁ I METODY}

Pacjenci. Badanie przeprowadzono zgodnie z założeniami Deklaracji Helsińskiej. Spośród 1435 chorych hospitalizowanych w Oddziale Chorób Infekcyjnych Dzieci i Hepatologii Dziecięcej KSS im. Jana Pawła II w 2016 roku, do badania włączono 462 kolejnych pacjentów, u których rozpoznano AGE. AGE definiowano jako nagłe wystąpienie u dotychczas zdrowego dziecka wymiotów i/lub biegunki, z lub bez towarzyszącej gorączki. Jako kryterium biegunki przyjęto oddawanie zwiększonej ilości stolca na dobę ( $\geq 3$ /dobę) lub zmianę konsystencji stolców na płynną lub półpłynną, albo pojawienie się stolców zawierających domieszkę krwi, ropy lub śluzu. Jako kryterium rozpoznania AGE przyjęto utrzymywanie się objawów do 2 tygodni. $Z$ badania wykluczono chorych $\mathrm{z}$ biegunką przetrwałą (trwającą $>$ $14 \mathrm{dni}$ ) oraz z biegunką przewlekłą (trwającą $>30 \mathrm{dni}$ ).

W badaniu retrospektywnym analizowano wiek, płeć, czynnik etiologiczny AGE, sezonowość zachorowania, długość hospitalizacji oraz objawy chorobowe (gorączka, wymioty, biegunka, oraz patologiczne domieszki w kale - krew/śluz). Rutynowo u każdego pacjenta zgłaszającego się z objawami AGE badano kał w kierunku zakaże- 
Classical cultural methods were used to detect aerobic bacteria such as Salmonella, Shigella, Yersinia enterocolitica or EPEC (15). Stool samples were cultured using the following types of agar media: MacConkey Agar (bioMerieux, Marcy-l'Étoile, France), Chromid ID CPSE (bioMerieux, Marcy-l'Étoile, France) and SS agar (bioMerieux, Marcy-l'Étoile, France). Specimens were incubated at $35 \pm 2{ }^{\circ} \mathrm{C}$ for 24 hours or at 28-30 ${ }^{\circ} \mathrm{C}$ for 48 hours to identify Yersinia enterocolitica on MacConkey agar $(15,16)$.

Antibiotic susceptibility was performed using a disc-diffusion test with Mueller Hinton 2 Agar (bioMerieux, Marcy-l'Étoile, France) (16). Determination of minimum inhibitory concentration were consistent with the European Committee on Antimicrobial Susceptibility Testing.

Also, qualitative immunochromatographic assays were performed. VIKIA Rota-Adeno test (bioMerieux, Marcy-l'Étoile, France) was used to detect rotavirus and adenovirus antigens and RIDA®QUICK Norowirus test (R-Biopharm AG, Dermstadt, Germany) to detect norovirus. In case of bacterial etiology of AGE, RIDA ${ }^{\circledR Q U I C K}$ Campylobacter test (R-Biopharm AG, Dermstadt, Gemany), C. DIFF QUIK CHEK COMPLETE test $\left(\right.$ TECHLAB $^{\circledR}$ Inc., Orlando, USA), One Step Salmonella Card test (CERTEST BIOTEC S.L., Zaragoza, Spain) and Card test for Yersinia enterocolitica O:3+O:9 (CERTEST BIOTEC S.L., Zaragoza, Spain) were performed. For parasitic infections, RIDA ${ }^{\circledR} Q U I C K$ Cryptosporidium/Giardia/Entamoeba Combi test (R-Biopharm AG, Dermstadt, Germany) was used. We did not culture stool samples for Campylobacter.

Statistical analysis. Categorical variables were presented as numbers (n) and percentages (\%). Continuous variables were presented as mean and standard deviation $( \pm)$ or median and quartiles, as appropriate. The $\chi^{2}$ test was used to compare distributions of categorical variables between independent groups. Two-sided $\mathrm{p}$-values of $<0.05$ were considered statistically significant. Statistical analysis was performed with Statistica 10.0 (StatSoft, Tulsa, USA).

\section{RESULTS}

Of the 462 children with AGE enrolled in this study, 451 were included in the analysis. Eleven patients were excluded because of their being in small groups of cases (5 patients with Clostridium difficile, 3 with Yersinia enterocolitica and 3 with Giardia lamblia).

Age. The median age of patients was 3.0 years [1.55.5], (minimum age -1 month, maximum 17 years). Eighty percent of all AGE cases occurred in children under 5 years of age and the largest group consisted of patients between 2 and 5 years $(p<0,001$ and $p=0,001$ respectively), (Tab. I). nia następującymi patogenami: Rotawirus, Norowirus, Adenowirus, Campylobacter, Salmonella oraz Yersinia enterocolitica. Ponadto u dzieci poniżej 2. roku życia kał badano również w kierunku infekcji enteropatogenną Escherichia coli (EPEC). W przypadku braku identyfikacji czynnika etiologicznego zachorowania i utrzymywania się biegunki, wykonywano badanie w kierunku infestacji pasożytniczej (Giardia lamblia, Entamoeba, Cryptosporydium). Dodatkowo u dzieci z czynnikami ryzyka (długotrwała antybiotykoterapia, wcześniejsze pobyty w szpitalu) próbki kału badano pod kątem zakażenia toksynotwórczym szczepem Clostridium difficile. Nie prowadzano badań wykrywających werotoksyczne szczepy Escherichia coli np. serotyp O:157:H7.

Badania mikrobiologiczne. Materiał od badanej grupy pacjentów (płynny lub półpłynny stolec) poddano analizie mikrobiologicznej wykorzystując do diagnostyki klasyczną metodę posiewu mikrobiologicznego stolca oraz screening, oparty o jakościowe testy immunochromatograficzne.

Klasyczną metodę posiewu mikrobiologicznego zastosowano celem prowadzenia hodowli w kierunku bakterii tlenowych, takich jak Salmonella, Shigella, Yersinia enterocolitica czy EPEC (15). Posiew stolca prowadzono wykorzystując następujące rodzaje pożywek mikrobiologicznych: MacConkey Agar (bioMerieux, Marcy-l'Étoile, Francja), Chromid ID CPSE (bioMerieux, Marcy-l'Étoile, Francja) oraz SS agar (bioMerieux, Marcy-l'Étoile, Francja). Posiany materiał inkubowano w temperaturze $35 \pm 2$ ${ }^{\circ} \mathrm{C}$ przez około $24 \mathrm{~h}$ oraz w zakresie temperatur $28-30^{\circ} \mathrm{C}$ przez $48 \mathrm{~h}$, aby umożliwić wzrost pałeczek z rodzaju Yersinia enterocolitica na podłożu MacConkeya $(15,16)$.

Oznaczenie lekooporności na określone antybiotyki prowadzono metodą dyfuzyjno - krążkową na podłożu Mueller Hinton 2 Agar (bioMerieux, Marcy-l’Étoile, Francja) (16). Wartości stref zahamowania wzrostu interpretowano wg. zaleceń European Committee on Antimicrobial Susceptibility Testing.

Poza klasyczną metodą posiewu stosowano także testy oparte o technikę chromatograficzną. Diagnostyka biegunek wirusowych wywołanych rotawirusem i adenowirusem oparta była o testy VIKIA Rota-Adeno (bioMerieux, Marcy-l'Étoile, Francja), natomiast norowirusem o testy RIDA®QUICK Norowirus (R-Biopharm AG, Dermstadt, Niemcy). Przy podejrzeniu etiologii bakteryjnej wykorzystywano następujące testy: RIDA®QUICK Campylobacter (R-Biopharm AG, Dermstadt, Niemcy), wykrywające antygeny Campylobacter jejuni $i$ coli, C. DIFF QUIK CHEK COMPLETE (TECHLAB ${ }^{\circledR}$ Inc., Orlando, USA) stosowane w diagnostyce toksynotwórczych szczepów Clostridium difficile, One Step Salmonella Card (CERTEST BIOTEC S.L., Zaragoza, Hiszpania) przy diagnostyce salmonellozy oraz Card Test (CERTEST BIOTEC S.L., Zaragoza, Hiszpania) wykrywający antygeny Yersinia enterocolitica O:3+0:9. 


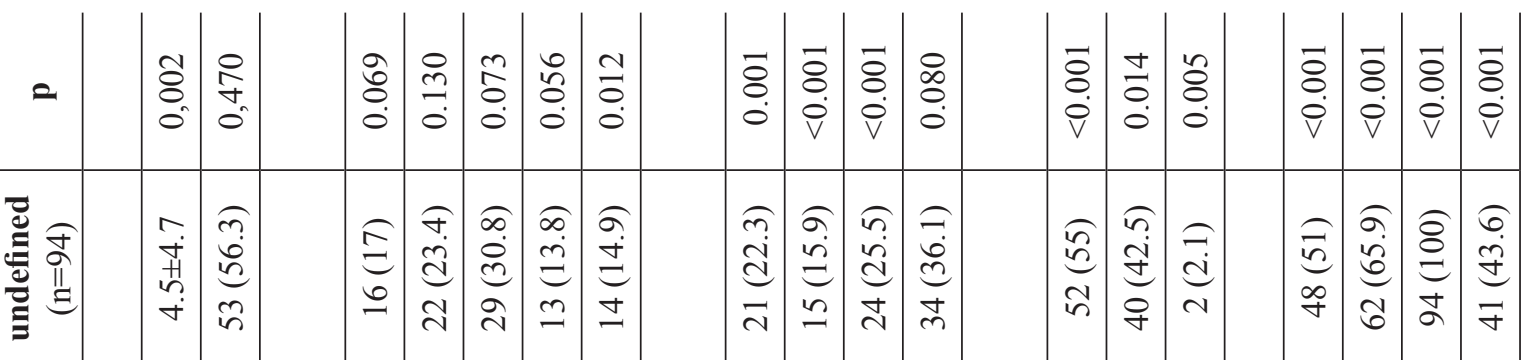

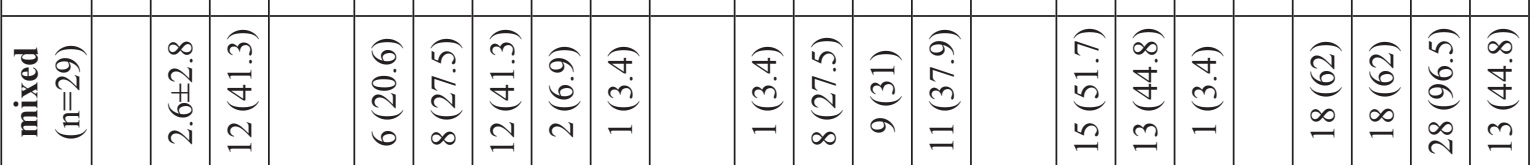

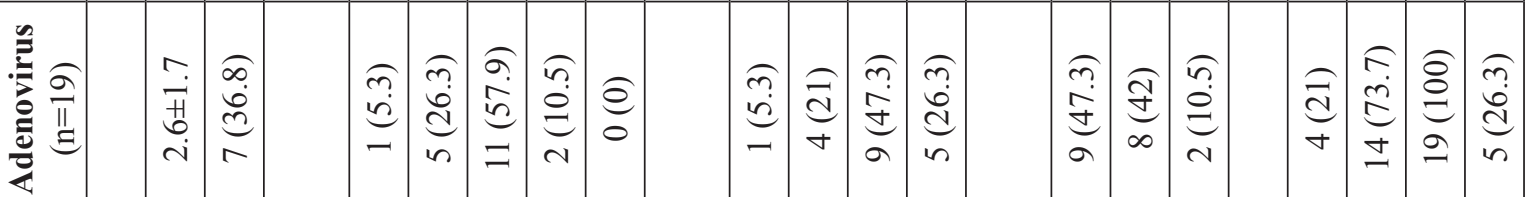

\begin{tabular}{|c|c|c|c|c|c|c|c|c|c|c|c|c|c|c|c|c|c|c|}
\hline 党 & $\begin{array}{l}\text { ry } \\
\text { in } \\
m \\
m\end{array}$ & $\begin{array}{c}\sigma \\
i \\
i \\
j \\
0 \\
i\end{array}$ & $\begin{array}{l}\infty \\
0 \\
0 \\
\sigma\end{array}$ & $\begin{array}{l}\widehat{a} \\
\stackrel{d}{d} \\
\simeq\end{array}$ & $\begin{array}{l}\infty \\
\dot{0} \\
\stackrel{0}{m} \\
\vec{m}\end{array}$ & $\underset{m}{\stackrel{\partial}{\dot{J}}}$ & $\begin{array}{l}\underset{\sigma}{\sigma} \\
\underset{\sigma}{0}\end{array}$ & 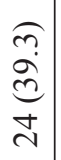 & $\begin{array}{l}\underset{f}{\sigma} \\
\stackrel{\bullet}{=} \\
0 \\
0\end{array}$ & $\begin{array}{l}\vec{\sigma} \\
\dot{\theta} \\
\sigma\end{array}$ & $\begin{array}{l}\underset{\infty}{0} \\
\stackrel{0}{0} \\
\stackrel{\sim}{2}\end{array}$ & $\begin{array}{l}\hat{\tau} \\
\stackrel{d}{d} \\
\stackrel{n}{e}\end{array}$ & $\begin{array}{l}\tilde{n} \\
\stackrel{+}{ \pm} \\
\stackrel{\sim}{\sim}\end{array}$ & 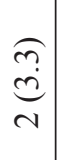 & 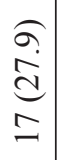 & 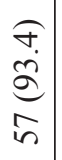 & 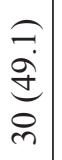 & $\begin{array}{l}\tilde{n} \\
e \\
\sigma \\
\sigma\end{array}$ \\
\hline
\end{tabular}

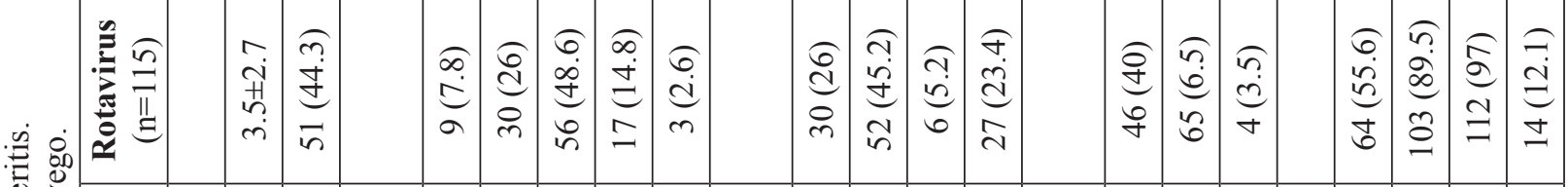

\begin{tabular}{|c|c|c|c|c|c|c|c|c|c|c|c|c|c|c|c|c|c|c|}
\hline 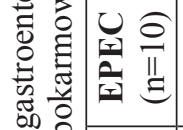 & 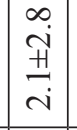 & 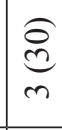 & 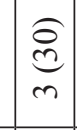 & $\underset{\sigma}{\stackrel{o}{q}}$ & $\underset{\sim}{\stackrel{d}{d}}$ & $\underset{-}{\stackrel{\vartheta}{\ominus}}$ & $\stackrel{\varrho}{0}$ & $\underset{-}{\stackrel{\vartheta}{\Xi}}$ & 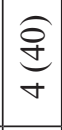 & $\underset{-}{\stackrel{\sigma}{\ominus}}$ & $\underset{\gamma}{\stackrel{o}{q}}$ & $\stackrel{\ominus}{\ominus}$ & $\begin{array}{c}\widehat{\delta} \\
0 \\
0\end{array}$ & $\begin{array}{l}\widehat{ఠ} \\
\text { ల్ల } \\
\end{array}$ & $\begin{array}{c}\stackrel{\varrho}{\Xi} \\
\therefore\end{array}$ & $\begin{array}{l}\widehat{\sigma} \\
i \\
i n\end{array}$ & $\begin{array}{l}\widehat{a} \\
a\end{array}$ & $\begin{array}{l}\widehat{\circ} \\
i n \\
\text { in }\end{array}$ \\
\hline 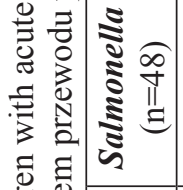 & 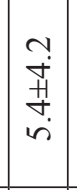 & 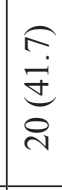 & 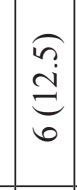 & 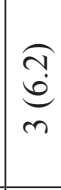 & $\begin{array}{l}\tilde{n} \\
\stackrel{2}{0} \\
a\end{array}$ & 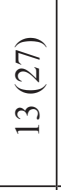 & $\stackrel{\substack{n \\
\pm}}{n}$ & 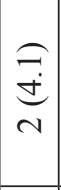 & 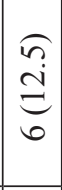 & $\mid \begin{array}{l}n \\
\tilde{a} \\
0 \\
0 \\
2\end{array}$ & $\begin{array}{l}\hat{\tilde{j}} \\
\stackrel{\text { v }}{\sim}\end{array}$ & 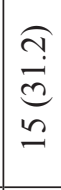 & $\begin{array}{c}\widehat{\Xi} \\
\mathfrak{d} \\
\underline{-}\end{array}$ & $\underset{d}{\overparen{d}}$ & $\begin{array}{l}\sigma \\
\dot{-} \\
\vdots \\
\dot{\sigma} \\
7\end{array}$ & 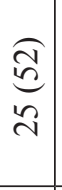 & $\begin{array}{c}\underset{8}{\varrho} \\
\stackrel{\infty}{+}\end{array}$ & $\begin{array}{l}7 \\
\infty \\
0 \\
m \\
m\end{array}$ \\
\hline
\end{tabular}

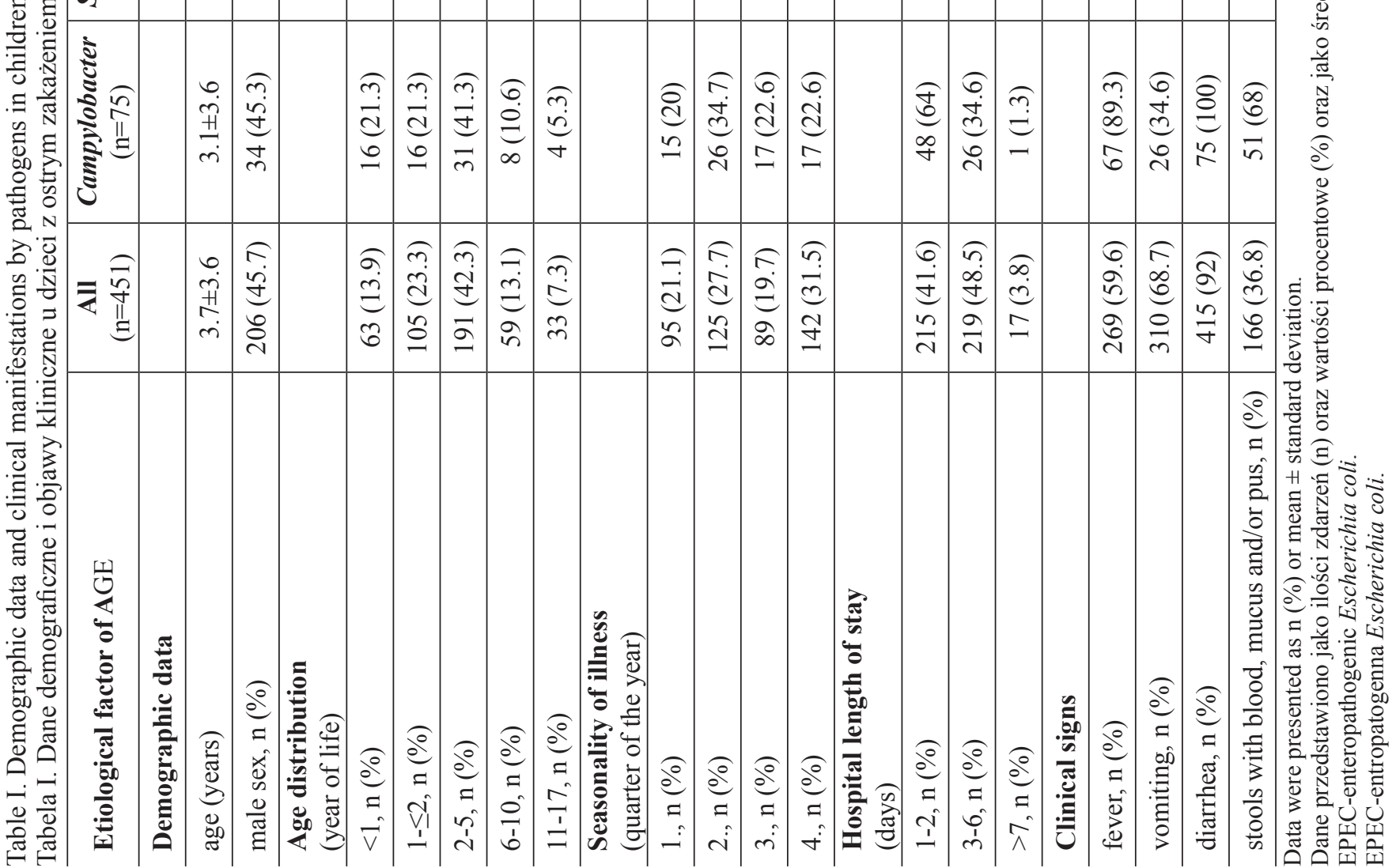




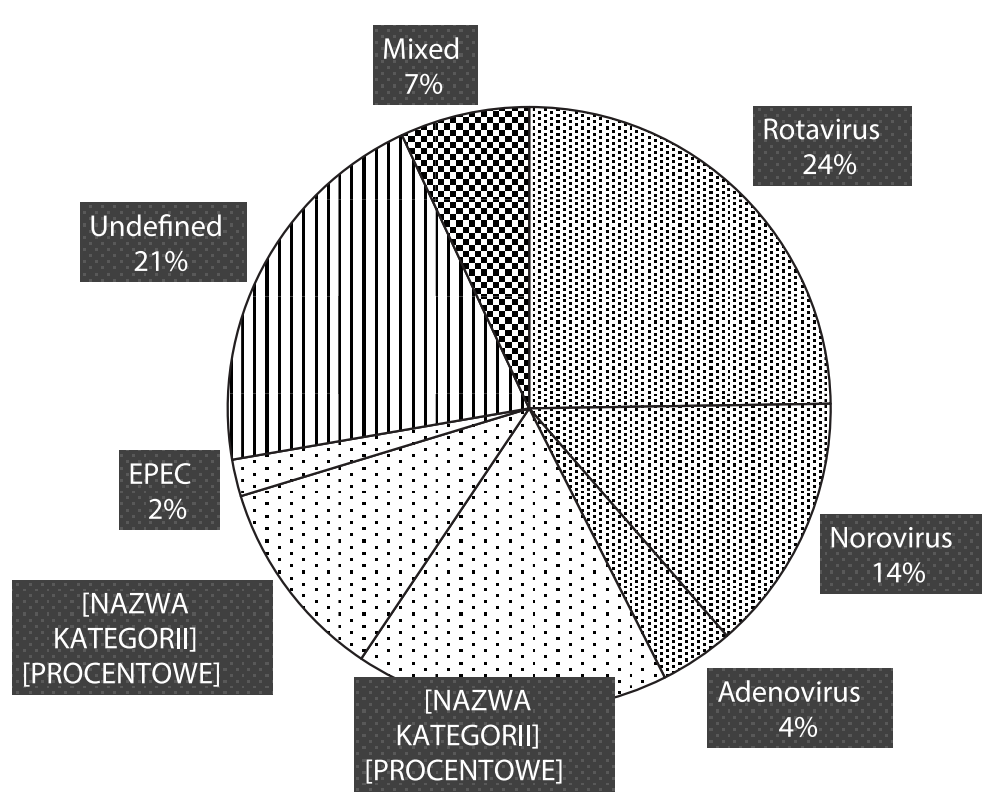

Fig. 1. The analysis of detected pathogens in children with acute gastroenteritis $(n=451)$. EPEC-enteropathogenic Escherichia coli.

Ryc. 1. Rozkład wykrytych patogenów u dzieci z ostrymi zakażeniami przewodu pokarmowego (n=451). EPEC-entropatogenna Escherichia coli.

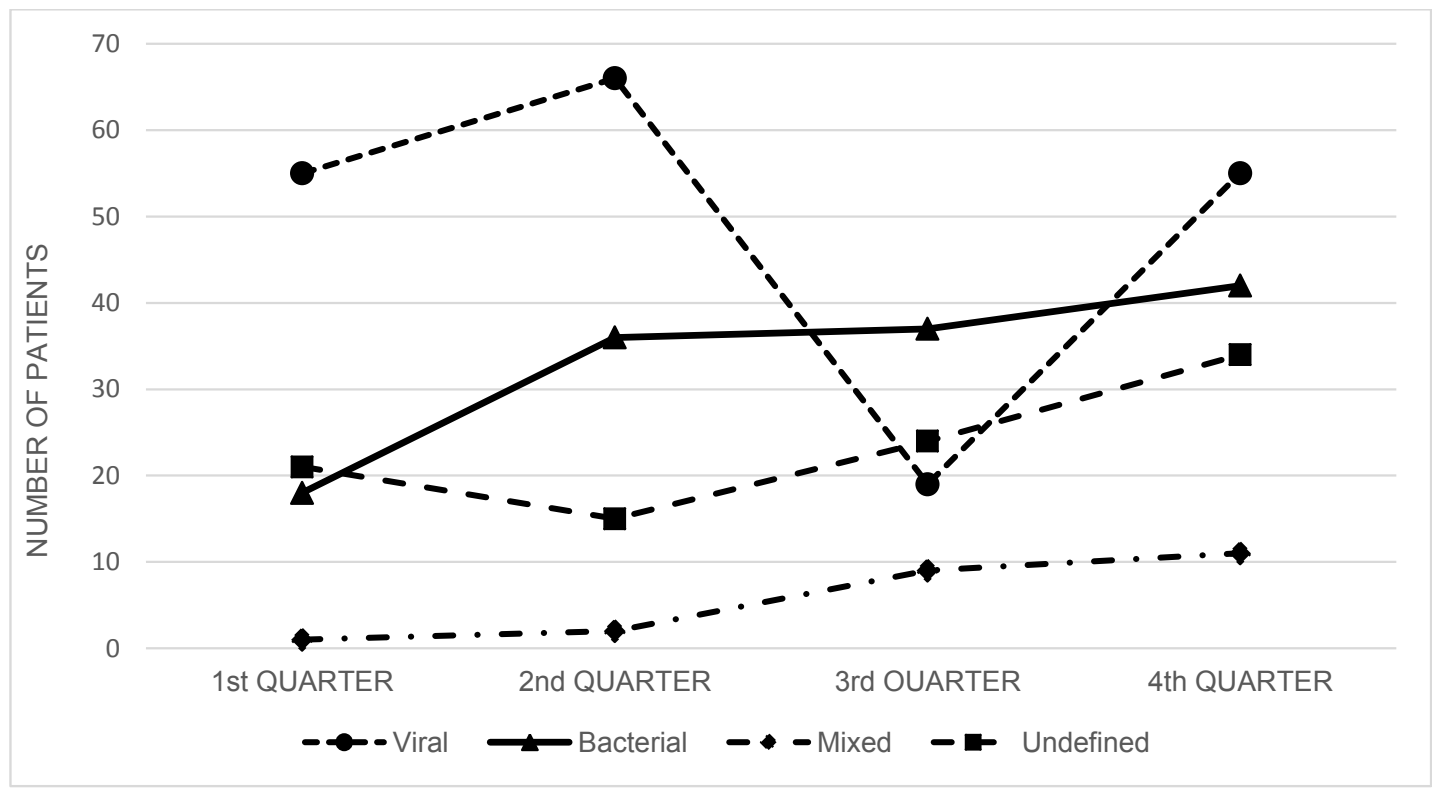

Fig. 2. Seasonal distrbution of pathogens in children with acute gastroenteritis.

Rys. 2. Sezonowy rozkład patogenów u dzieci z ostrymi zakażeniami przewodu pokarmowego.

Sex. The ratio of male and female children with AGE were similar ( $46 \%$ girls, $\mathrm{p}=0,470)$. No differences in gender were noted between analyzed groups regarding frequencies of occurrence of clinical signs, etiologic factors, seasonality of illness, age and hospital length of stay $(\mathrm{p}=0,867, \mathrm{p}=0,138, \mathrm{p}=0,358$, $\mathrm{p}=0,481$ and $\mathrm{p}=0,219$ respectively ), (Tab. I).

Etiologic factor. Viral pathogens were the leading cause of AGE $(p=0,001)$. Among the viruses, rotavirus was the most commonly identified pathogen $(59 \%)$, followed by norovirus infection $(31 \%),(p=0,001)$. Campylobacter was the most common in the bacterial pathogens $(56 \%)$, followed by Salmonella $(36 \%)$,
W diagnostyce pasożytniczej stosowano test RIDA®QUICK Cryptosporidium/Giardia/Entamoeba Combi (R-Biopharm AG, Dermstadt, Niemcy), w kierunku antygenów Cryptosporidium parvum, Giardia lamblia oraz Entamoeba histolytica sensu lato. Nie wykonywano posiewów stolca w celu hodowli pałeczek Campylobacter.

Analiza statystyczna. Zmienne jakościowe przedstawiono za pomocą obserwowanej liczby zdarzeń (n) oraz wartości procentowych (\%), zmienne ciągłe przedstawiono za pomocą wartości średniej i odchylenia standardowego $( \pm)$ lub jako mediana i przedział międzykwartylowy. Porównanie parametrów jakościowych przeprowadzono za pomocą testu $\chi^{2}$. Wyniki uznano za 
$(p=0,05)$, (Tab. I), (Fig. 1). Among the mixed AGE patients, rotavirus with EPEC infections were the most frequently observed, but without significant difference $(\mathrm{p}=0,459)$, (Tab. II).

Table II. Analysis of mixed pathogens in children with acute gastroenteritis.

Tabela II. Rozkład patogenów mieszanych u dzieci z ostrymi zakażeniami przewodu pokarmowego.

\begin{tabular}{|l|c|}
\hline Mixed patogens & $\begin{array}{c}\text { Number } \\
\text { of patients } \\
(\mathrm{n}=29)\end{array}$ \\
\hline Bacterial+Viral & $\mathbf{2 1}$ \\
\hline EPEC+Rotavirus & 6 \\
\hline EPEC+Norovirus & 3 \\
\hline EPEC+Adenovirus & 2 \\
\hline Salmonella+Rotavirus & 4 \\
\hline Salmonella+Norovirus & 2 \\
\hline Salmonella+Adenovirus & 1 \\
\hline Campylobacter+Rotavirus & 1 \\
\hline Campylobacter+Adenovirus & 1 \\
\hline Campylobacter+Salmonella + Norovirus & 1 \\
\hline Bacterial & $\mathbf{5}$ \\
\hline Campylobacter+EPEC & 4 \\
\hline Campylobacter+Salmonella & 1 \\
\hline Viral & $\mathbf{3}$ \\
\hline Rotavirus+Norovirus & 2 \\
\hline Rotavirus+Adenovirus & 1 \\
\hline EPEC-enteropathogenic Escherichia coli. & \\
EPEC-entropatogenna Escherichia coli. & \\
\hline
\end{tabular}

Seasonal pattern. A seasonal pattern was observed for etiological factors of AGE $(p<0,001)$. Cases of viral gastroenteritis increased during the first and second quarter of the year, whereas bacterial pathogens were most common during the summer, i.e. in the third quarter of the year $(p<0,001)$. Rotavirus infections dominated $(45 \%)$ during the second quarter of the year, while during the third quarter they were rarest $(5 \%),(\mathrm{p}=0,05)$, similar to norovirus gastroenteritis $(7 \%)$. No seasonal trend was observed for Campylobacter gastroenteritis. Salmonella infections occurred mainly in the second and third quarter of the year ( $\mathrm{p}=0,001)$, (Tab. I), (Fig. 2-4).

Hospital length of stay. The average length of hospital stay was 3,1 $\pm 1,6$ days (minimum 1, maximum 14 ) and only 17 children (4\%) stayed more than 6 days. The longest length of stays was related to patients with EPEC and Salmonella $(p<0,001)$. There was a correlation between length of stay in hospital and seasonality of illness and the shortest hospitalization was observed in the fourth quarter of the year $(\mathrm{p}=0,036)$, (Tab. I). statystycznie istotne przy poziomie istotności $p<0,05$. Analiza statystyczna została wykonana za pomocą programu Statistica 10.0 (StatSoft, Tulsa, USA).

\section{WYNIKI}

Spośród 462 chorych z rozpoznaniem AGE analizą statystyczną objęto 451 pacjentów. $Z$ analizy wykluczono 11 pacjentów ze względu na ilościowo niewielkie grupy (5 chorych, u których czynnikiem etiologicznym było Clostridium difficile, u 3 Yersinia enterocolitica oraz 3 z rozpoznaniem Giardia lamblia).

Wiek. Mediana wieku wynosiła 3,0 roku [1,5-5,5], (min.-1 miesiąc, maksimum 17 lat). 80\% wszystkich przypadków AGE wystąpiło u dzieci poniżej 5 r.ż., a najliczniejszą grupę ( $\mathrm{n}=191,42 \%$ ) stanowily dzieci w wieku od 2 do 5 lat (odpowiednio $\mathrm{p}<0,001 \mathrm{i} \mathrm{p}=0,001$ ), (Tab. I)

Płeć. W przestawionym badaniu nie stwierdzono różnic częstości występowania AGE w zależności od płci ( $46 \%$ dziewczynek, $p=0,470)$. Płeć nie odgrywała również roli w częstości występowania objawów klinicznych, rodzaju czynnika etiologicznego, sezonowości oraz wieku zachorowania a także czasu trwania hospitalizacji (odpowiednio $\mathrm{p}=0,867, \mathrm{p}=0,138, \mathrm{p}=0,358$, $\mathrm{p}=0,481 \mathrm{i} \mathrm{p}=0,219)$, (Tab. I).

Czynnik etiologiczny. Najczęstszym (43\%) czynnikiem etiologicznym AGE był czynnik wirusowy $(\mathrm{p}=0,001)$. Wśród czynników wirusowych dominowały $(59 \%)$ zakażenia spowodowane przez rotawirusy $(\mathrm{p}=0,001)$. Infekcje norowirusem odpowiedzialne były za 31\% wszystkich przypadków wirusowego AGE. Natomiast spośród czynników bakteryjnych najczęstsze były $(56 \%)$ zakażenia wywołane przez Campylobacter, przed infekcjami Salmonella $(36 \%)(\mathrm{p}=0,05)$, (Tab. I), (Ryc. 1). Spośród zakażeń mieszanych najczęściej występowało zakażenie wywołane przez rotawirus i EPEC, jednak bez istotnych statystycznie różnic w porównaniu do innych zakażeń mieszanych $(\mathrm{p}=0,459)$, (Tab. II).

Sezonowość. W badaniu zaobserwowano zależność pomiędzy czynnikiem etiologicznym a kwartałem roku wystąpienia zachorowania $(p<0,001)$. Czynnik wirusowy był głównym czynnikiem etiologicznym AGE w 1. i 2. kwartale roku, natomiast etiologia bakteryjna dominowała w okresie letnim, tj. w 3. kwartale roku ( $p<0,001)$. Do AGE o etiologii rotawirusowej dochodziło najczęściej w 2 . kwartale (45\%) a najrzadziej w 3. kwartale roku (5\%), $(\mathrm{p}=0,05)$. Podobnie infekcje o etiologii norowirusowej miały najniższą częstość występowania $(7 \%)$ w 3 . kwartale roku $(\mathrm{p}=0,01)$. Nie zaobserwowano zależności pomiędzy zakażeniem pałeczkami Campylobacter a porą roku. W przypadku zakażeniami Salmonellą stwierdzono istotnie częstsze występowanie choroby w 3. i 4. kwartale roku $(p=0,001),($ Tab. I), (Ryc. 2-4). 


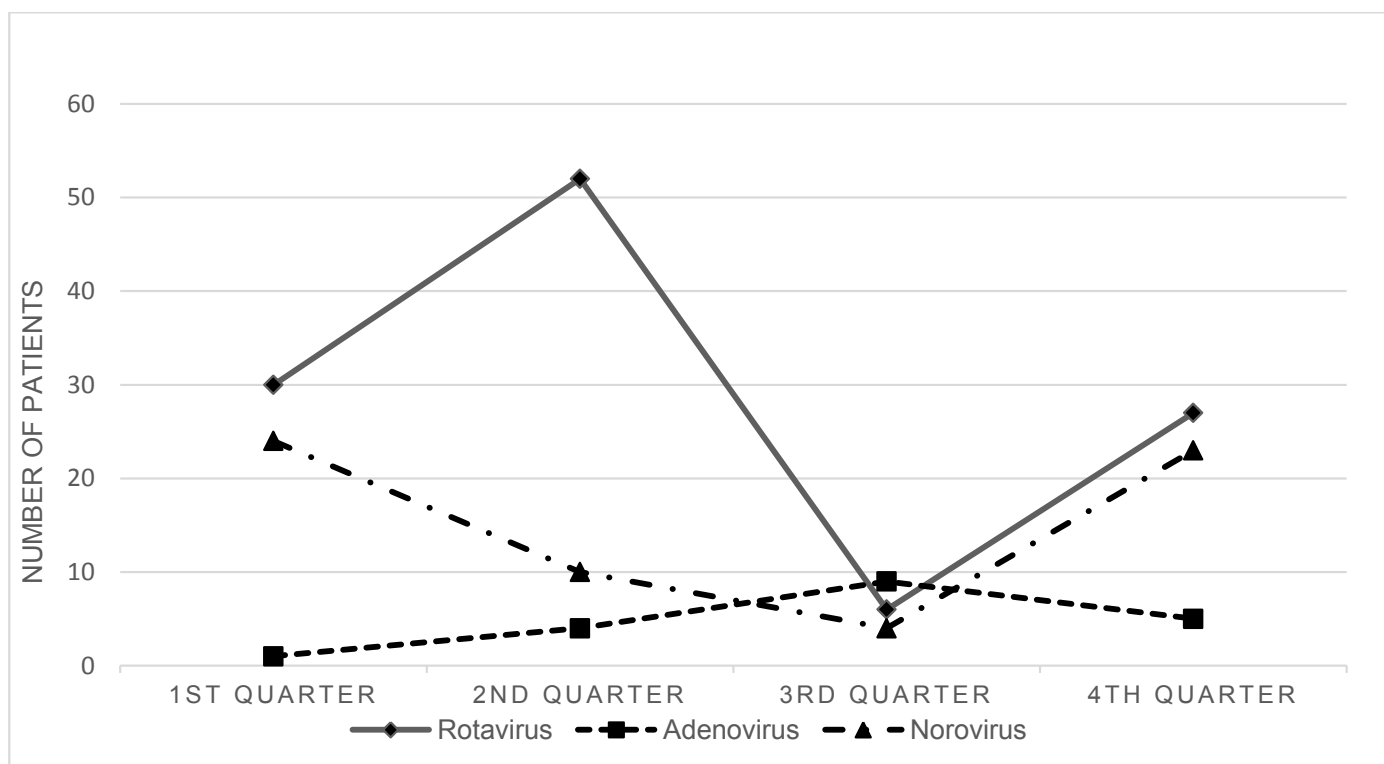

Fig 3. Seasonal distribution of viral pathogens in children with acute gastroenteritis.

Ryc 3. Sezonowy rozkład patogenów wirusowych u dzieci z ostrymi zakażeniami przewodu pokarmowego.

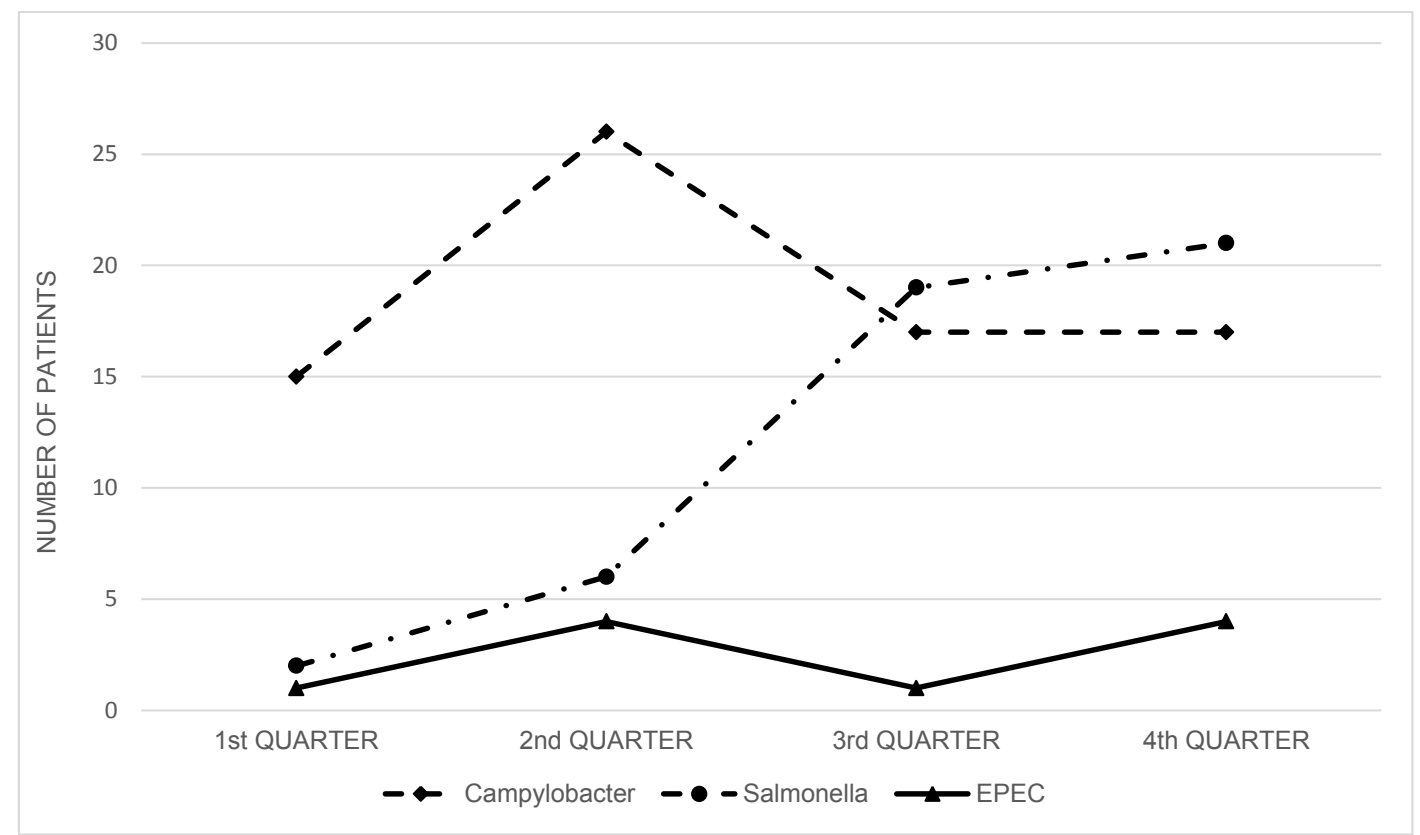

Fig. 4. Seasonal distribution of bacterial pathogens in children with acute gastroenteritis. EPEC-enteropathogenic Escherichia coli.

Ryc. 4. Sezonowy rozkład patogenów bakteryjnych u dzieci z ostrymi zakażeniami przewodu pokarmowego. EPEC-entropatogenna Escherichia coli.

Clinical signs. There was a correlation between etiological factors and clinical signs of AGE. Fever, diarrhea and stools with blood, mucus and/or pus occurred more frequent in patients with bacterial AGE, while vomiting appeared more often in children with viral gastroenteritis ( $p<0,001$ for all). We also found a correlation between age of children and analyzed signs. Vomiting occurred more often in patients above 2 years of age $(p<0,001)$, whereas stools with blood, mucus and/or pus appeared more frequently in children under 2 years $(\mathrm{p}=0,008)$, (Tab. I).
Czas hospitalizacji. Średnia długość hospitalizacji wynosiła 3,1 $\pm 1,6$ doby (minimum 1 , maksimum 14). Tylko 17 chorych (4\%) wymagało hospitalizacji powyżej 6 dób. Najdłuższego pobytu w szpitalu wymagali chorzy, u których przyczyną AGE była EPEC i Salmonella (dla obu $\mathrm{p}<0,001$ ). W badaniu stwierdzono również zależność pomiędzy długością hospitalizacji a kwartałem zachorowania. Najkrótszy czas hospitalizacji miał miejsce w czwartym kwartale roku $(\mathrm{p}=0,036),($ Tab. I) 


\section{DISCUSSION}

According to the European Food Safety Authority and European Centre for Disease Prevention and Control, in the EU since 2005, Campylobacter AGE is more common than Salmonella gastroenteritis $(10,11)$. In Poland, where routine diagnosis of Campylobacter species are not performed, Salmonella AGE is still the most commonly notified infection (14). In this study we showed that routine diagnosis of Campylobacter in all children with AGE is associated with higher than actually reported incidences of campylobacteriosis. Viral gastroenteritis is regarded as the most frequent cause of AGE in our hospital. Rotavirus was the most commonly identified pathogen, followed by norovirus infections, which is in line with other reports $(1,17,18)$.

Our study showed that the largest group of patients comprise of children between 2 and 5 years of age and this finding is consistent with other study results $(17,19,20)$. Also in line with other studies, the incidence of AGE in boys was slightly higher than in girls $(21,22)$.

A seasonal trend for AGE was observed in many studies. A. López-de-Andrés et al. showed seasonal distribution of rotavirus gastroenteritis with peak incidence in winter (23). In our study, a seasonal pattern was also observed. Rotavirus infections dominated over the second quarter of the year, while during the third quarter they were rarest, similar to norovirus infections (7\% of cases), as in other studies (17). Salmonella infections occurred mainly in the second and third quarter of the year and we did not observe a seasonal trend for Campylobacter gastroenteritis, only a statistically insignificant prevalence of Campylobacter disease in the second quarter. This finding is consistent with previous studies that demonstrated a seasonal summer pattern of Salmonella and no seasonality in cases of Campylobacter gastroenteritis (24).

There was a correlation between hospital length of stay and etiological pathogen or month of admission. The longest length of stay was related to patients with EPEC and Salmonella. The shortest hospitalization stays were during the autumn months when viral infections prevailed, a finding that was not observed in other studies. Our analysis reveled that children under 2 years of age have had the longest hospital stays and this observation is consistent with other study results $(19,25)$.

The correlations between clinical signs and etiological factors in this study were consistent with other results $(17,20,26,27)$. Fever, diarrhea and stools with blood, mucus and/or pus occurred more frequent in patients with bacterial AGE, while vomiting appeared more often in children with viral infections.
Objawy kliniczne. W przedstawionej analizie wykazano zależność pomiędzy czynnikiem etiologicznym a rodzajem objawów klinicznych. Gorączka, biegunka oraz patologiczne domieszki w kale dominowały u pacjentów z bakteryjną etiologią AGE (dla wszystkich $p<0,001)$. Natomiast wymioty występowały znamiennie częściej u dzieci z zakażeniami wirusowymi $(\mathrm{p}<0,001)$. Również wiek dziecka miał wpływ na częstość występowania analizowanych objawów klinicznych. Dzieci powyżej 2. r.ż. częściej miały wymioty niż młodsi pacjenci $(\mathrm{p}<0,001)$. $Z$ kolei u dzieci poniżej 2. r.ż. statystycznie częściej występowały patologiczne domieszki w kale $(\mathrm{p}=0,008)$, (Tab. I).

\section{DYSKUSJA}

Wg raportów Europejskiego Urzędu ds. Bezpieczeństwa Żywności (European Food Safety Authority) oraz Europejskiego Centrum ds. Zapobiegania i Kontroli Chorób (European Centre for Disease Prevention and Control) od 2005 roku, w krajach członkowskich UE, pałeczki Campylobacter powodują więcej przypadków AGE u dzieci niż bakterie Salmonella $(10,11)$. W Polsce, gdzie nie stosuje się standardowo testów diagnostycznych w kierunku kampylobakteriozy, wśród bakteryjnych przyczyn AGE nadal dominują infekcje wywołane pałeczkami Salmonella (14). W przedstawionym badaniu wykazano, że rutynowe zastosowanie testów diagnostycznych w kierunku kampylobakteriozy u wszystkich dzieci z AGE może pokazać większą liczbę zachorowań na kampylobakteriozę niż aktualnie rejestrowana.

Analiza całościowej epidemiologii zachorowań na AGE w naszym Oddziale wykazała, że najczęstszą przyczyną są zakażenia wirusowe. Nasze wyniki potwierdzają znaczący udział norowirusa jako drugiej po rotawirusie przyczynie AGE, co jest zgodne z pracami innych autorów $(1,17,18)$.

Większość literatury wykazuje, że AGE najczęściej dotyczą niemowląt oraz małych dzieci do 5 r.ż. $(17,19,20)$. Nasze badanie potwierdza te obserwacje, gdyż w przedstawionej analizie dominowały dzieci poniżej 5 r.ż., a najliczniejszą grupę chorych stanowiły dzieci pomiędzy 2. a 5. r.ż. Również rozkład płci, w którym nieznacznie dominowali chłopcy, był zgodny z innymi doniesieniami $(21,22)$.

Istnieją liczne badania oceniające sezonowość zachorowań na AGE, w zależności od wywołującego go czynnika etiologicznego. Szczyt zachorowań na infekcje rotawirusowe w miesiącach jesienno-zimowo-wiosennych w porównaniu do letnich wykazał A. López-de-Andrés i wsp. (23). W naszym badaniu również najwięcej infekcji rotawirusowych obserwowano w tym okresie, ze szczytem zachorowań w 2. kwartale roku. Podobnie było w przypadku etiologii 
This study has several limitations. The size of the study group was limited. The data covered gastroenteritis cases entered to a single center and covering a period of 12 months. Future studies should include patients from other hospitals with a longer observation time. This would allow a more accurate assessment of the incidence and prevalence of AGE in Poland. We did not culture stool samples for Campylobacter species, although this method is considered as the gold standard of identification of campylobacteriosis (28). Culturing stool specimens for Campylobacter species is an expensive and timeconsuming process and to obtain results we have to usually wait about 5-7 days. This is the reason this method of Campylobacter identification is performed in only a few centers in Poland $(28,29,30)$. The advantages of the immunochromatographic assays for Campylobacter diagnosis are a shorter waiting time for the results (15 minutes) and the high sensitivity and specificity of this method. Finally, unidentified AGE consisted of a large group of infections in this study (Tab. I). The most probable reason for this is that tests for other pathogens of gastroenteritis, such as astrovirus, human bocavirus or sapovirus, were not performed. This is consistent with the results of other studies, that demonstrated a $30-40 \%$ share of unidentified pathogens in etiology of AGE $(31,32)$. It would be of interest to assess associations between the clinical signs and the markers of inflammation during infection.

\section{SUMMARY AND CONCLUSIONS}

This study showed that routine diagnosis of Campylobacter in all children with AGE, based on immunochromatographic assays, is associated with a higher than reported prevalence of campylobacteriosis.

\section{REFERENCES}

1. Akan H, Izbirak G, Gürol Y, et al. Rotavirus and adenovirus frequency among patients with acute gastroenteritis and their relationship to clinical parameters: A retrospective study in Turkey. Asia Pac Fam Med 2009;8:8.

2. Tate JE, Burton AH, Boschi-Pinto C, et al. Global, regional, and national estimates of rotavirus mortality in children $<5$ years of age, 2000-2013. Clin Infect Dis 2016;62:96-105.

3. Friesema IH, de Boer RF, Duizer E, et al. Etiology of acute gastroenteritis in children requiring hospitalization in the Netherlands. Eur J Clin Microbiol Infect Dis 2012;31:405-15.

4. Gimenez-Sanchez F, Delgado-Rubio A, Martinon-Torres F, et al. Rotascore: Research Group norowirusowej, w 3. kwartale roku miało miejsce tylko 7\% wszystkich zachorowań o tej etiologii, co jest zgodne z obserwacjami innych autorów (17). W prezentowanym badaniu najwięcej zakażeń pałeczką Salmonella miało miejsce w 3. i 4. kwartale, a najmniej 1. kwartale roku. W naszej pracy nie zauważono natomiast trendu sezonowego w przypadku zakażeń Campylobacter, jedynie niewielką, nieistotną statystycznie przewagę zachorowań w 2 . kwartale roku. Wyniki te są zgodne z innymi doniesieniami, w których częściej obserwowano zakażenia pałeczkami Salmonella w miesiącach letnich, a w przypadku infekcji Campylobacter nie zauważono sezonowości zachorowań (24).

Czas hospitalizacji w prezentowanym badaniu zależał od czynnika etiologicznego oraz od okresu zachorowania. Najdłuższej hospitalizacji wymagali chorzy z AGE wywołanym EPEC oraz pałeczkami Salmonella. Najkrótszy pobyt w szpitalu korelował z kolei z zachorowaniami w miesiącach jesiennych (wówczas występowała przewaga infekcji wirusowych). W pracach innych autorów nie zauważono podobnego związku z długością hospitalizacji, wykazano natomiast wydłużenie czasu pobytu w szpitalu u dzieci młodszych, poniżej 1-2 r.ż. $(19,25)$. Podobnie w przedstawionej analizie, dzieci poniżej 2. r.ż. częściej hospitalizowane były dłużej niż dzieci starsze.

Występowanie objawów chorobowych w zależności od czynnika etiologicznego, pokazanych w prezentowanej pracy, pokrywa się z doniesieniami innych autorów $(17,20,26,27)$. Gorączka, biegunka oraz patologiczne domieszki w kale częściej obserwowano $\mathrm{w}$ infekcjach bakteryjnych, natomiast w AGE o etiologii wirusowej znamiennie częściej występowały wymioty.

Opisane badanie ma szereg ograniczeń. Przede wszystkim liczebność analizowanych grup jest niewielka. Dodatkowo analizie poddano zachorowania jedynie z okresu dwunastu miesięcy, ponadto tylko $\mathrm{z}$ jednego szpitala. Większa liczba zrekrutowanych pacjentów, z szerszego przedziału czasowego i z większej liczbie ośrodków, pozwoliłaby na dokładniejszą analizę epidemiologii AGE w Polsce oraz na obserwacje trendów w zachorowaniach dzieci na przestrzeni kilku lat. Ponadto w celu identyfikacji pałeczek z rodzaju Campylobacter w naszym ośrodku nie wykonywano hodowli. Złotym standardem w diagnostyce kampylobakteriozy jest wciąż metoda izolacji i hodowli tych drobnoustrojów (28). Metoda ta jest jednak droga i czasochłonna. Zniechęcać może również długi czas oczekiwania na wynik (nawet 5-7 dni). Dlatego diagnostyka kampylobakteriozy w oparciu o posiew prowadzona jest $\mathrm{w}$ Polsce $\mathrm{w}$ niewielu ośrodkach $(28,29,30)$. Zaletą stosowanego przez nas testu immunochromatograficznego wykrywającego antygeny Campylobacter jejuni o coli jest krótki czas ocze- 
Multicenter prospective study analysing the role of rotavirus on acute gastroenteritis in Spain. Acta Paediatr 2010;99:738-42.

5. Aydin H, Aktaş O. Rotavirus genotypes in children with gastroenteritis in Erzurum: first detection of G12P[6] and G12P[8] genotypes in Turkey. Gastroenterology Review 2017; 12:122-7.

6. Hungerford D, Smith K, Tucker A, et al. Population effectiveness of the pentavalent and monovalent rotavirus vaccines: a systematic review and meta-analysis of observational studies. BMC Infect Dis 2017;17:569.

7. Payne DC, Vinjé J, Szilagyi PG, et al. Norovirus and medically attended gastroenteritis in U.S. children. N Engl J Med 2013;368:1121-30.

8. Tate JE, Burton AH, Boschi-Pinto C, et al. 2008 estimate of worldwide rotavirus-associated mortality in children younger than 5 years before the introduction of universal rotavirus vaccination programmes: a systematic review and meta-analysis. Lancet Infect Dis 2012;12:136-41.

9. Soriano-Gabarro M, Mrukowicz J, Vesikari T, et al. Burden of Rotavirus Disease in European Union Countries. Pediatr Infect Dis J 2006;25:7-11.

10. EFSA (European Food Safety Authority) and ECDC (European Centre for Disease Prevention and Control), 2015. The European Union summary report on trends and sources of zoonoses, zoonotic agents and food-borne outbreaks in 2014. EFSA Journal 2015;13:4329.

11. Kaakoush NO, Castaño-Rodríguez N, Mitchell HM, et al. Global epidemiology of Campylobacter infection. Clin Microbiol Rev 2015;28: 687720.

12. Bless PJ, Schmutz C, Mäusezahl D. The recurrent campylobacteriosis epidemic over Christmas and New Year in European countries, 2006-2014. BMC Res Notes 2017;10:266.

13. Choroby zakaźne i zatrucia w Polsce w 2015 roku. Narodowy Instytut Zdrowia Publicznego-Państwowy Zakład Higieny-Zakład Epidemiologii, Główny Inspektorat Sanitarny-Departament Zapobiegania oraz Zwalczania Zakażeń i Chorób Zakaźnych u Ludzi, Warszawa 2016; 16. www.pzh. gov.pl.

14. Choroby zakaźne i zatrucia w Polsce w 2016 roku. Narodowy Instytut Zdrowia Publicznego-Państwowy Zakład Higieny-Zakład Epidemiologii, Główny Inspektorat Sanitarny-Departament Zapobiegania oraz Zwalczania Zakażeń i Chorób Zakaźnych u Ludzi, Warszawa 2017; 16. www.pzh. gov.pl

15. Murray P.R, Rosenthal K.S, Pfaller M.A. Medical Microbiology Wyd. 6 Philadelphia: Elsevier;2009: 293-307. kiwania na wynik (15 minut) oraz wysoka czułość i specyficzność testu. W naszym badaniu, dużą część stanowią tzw. biegunki nieokreślone (Tab. I). Takie przypadki wynikają prawdopodobnie z braku wykonywania w naszym ośrodku badań w kierunku innych patogenów wywołujących AGE, jak astrowirus, ludzki bocawirus, sapowirus. $Z$ analizy piśmiennictwa wynika, że również w innych ośrodkach około 30-40 \% stanowią biegunki z nieustalonym czynnikiem etiologicznym $(31,32)$. Ciekawych informacji mogłaby dostarczyć również analiza zależności pomiędzy przebiegiem klinicznym AGE a parametrami odpowiedzi zapalnej, towarzyszącej infekcjom.

\section{PODSUMOWANIE I WNIOSKI}

Przedstawione badanie wykazało, że rutynowe wykonywanie diagnostyki w kierunku kampylobakteriozy u dzieci z AGE, w oparciu o testy immunochromatograficzne, prawdopodobnie zwiększy wykrywalność pałeczek Campylobacter jako czynnika etiologicznego.

16. Szewczyk E.M. Diagnostyka mikrobiologiczna. Wyd. 2 Warszawa: Wyd. Naukowe PWN; 2013: 131-145.

17. Oldak E, Sulik A., Rozkiewicz D, et al. Norovirus infections in children under 5 years of age hospitalized due to the acute viral gastroenteritis in northeastern Poland. Eur J Clin Microbiol Infect Dis 2012; 31: 417-22.

18. Räsänen S, Lappalainen S, Salminen $M$, et al. Noroviruses in children seen in a hospital for acute gastroenteritis in Finland. Eur $\mathrm{J} \mathrm{Pe}$ diatr 2011;170:1413-18.

19. Smok B, Zieniewicz-Cieślik K, Smukalska E, et al. Acute diarrhoea induced by rotavirus in children hospitalysed in Provincial Hospital for Infectious Diseases in Bydgoszcz in 2014 year. Przegl Epidemiol 2016;70:462-70.

20. Nirwati H, Saifudin Hakim M, Aminah S, et al. Identification of Rotavirus Strains Causing Diarrhoea in Children under Five Years of Age in Yogyakarta, Indonesia. Malays J Med Sci 2017;24: 68-77.

21. Yang SY, Hwang KP, Wu FT, et al. Epidemiology and Clinical Peculiarities of Norovirus and Rotavirus Infection in Hospitalized Young Children with Acute Diarrhea in Taiwan, 2009. J Microbiol Immunol Infect 2010;43:506-14.

22. Liu L, Qian Y, Zhang Y, et al. Epidemiological aspects of rotavirus and adenovirus in hospitalized children with diarrhea: a 5-year survey in Beijing. BMC Infectious Diseases 2016; 16:508. 
23. López-de-Andrés A, Jiménez-García R, Carrasco-Garrido P, et al. Hospitalizations associated with rotavirus gastroenteritis in Spain, 2001-2005. BMC Public Health 2008;8:109.

24. Tseng CF, Chiu NC, Huang CY, et al. The epidemiology of non-typhoidal Salmonella gastroenteritis and Campylobacter gastroenteritis in pediatric inpatients in northern Taiwan. J Microbiol Immunol Infect 2017; doi:10.1016/j.jmii.2017.08.021.

25. Huang IF, Kao CH, Lee WY, et al. Clinical Manifestations of Nontyphoid Salmonellosis in Children Younger than 2 Years Old-Experiences of a Tertiary Hospital in Southern Taiwan. Pediatrics and Neonatology 2012;53:193-8.

26. Fletcher S, Sibbritt D, Stark D, et al . Descriptive epidemiology of infectious gastrointestinal illnesses in Sydney, Australia, 2007-2010. Western Pac Surveill Response J 2015;6:7-16.

27. Koukou D, Chatzichristou P, Trimis G, et al. Rotavirus Gastroenteritis in a Neonatal Unit of a Greek Tertiary Hospital: Clinical Characteristics and Genotypes. PLoS ONE. 2015;10:e0133891. doi. org/10.1371/journal.pone.0133891.

28. Rokosz N, Rastawicki W, Wołkowicz T. Mikrobiologiczna diagnostyka zakażeń wywołanych przez pałeczki Campylobacter jejuni i Campylobacter coli u ludzi. Postępy Hig Med Dosw 2014; 68:48-56
29. Sadkowska-Todys M., Kucharczyk B. Kampylobakterioza w Polsce w 2013 i 2014 roku. Przegl Epidemiol 2016;70:209-15.

30. Szczepańska B, Andrzejewska M, Śpica D, et al. Campylobacter spp. - niedoceniany w Polsce czynnik etiologiczny zakażeń przewodu pokarmowego. Probl Hig Epidemiol 2014;95:574-79.

31. Rosenfeldt V, Vesikari T, Pang XL, et al. Viral etiology and incidence of acute gastroenteritis in young children attending day-care centers. Pediatr Infect Dis J 2005;24:962-5.

32. Chih-Jung Ch, Fang-Tzy W, Yhu-Chering H, et al. Clinical and Epidemiologic Features of Severe Viral Gastroenteritis in Children: A 3-Year Surveillance, Multicentered Study in Taiwan With Partial Rotavirus Immunization. Medicine (Baltimore). 2015; 94: e1372.

Received: 16.05.2018

Accepted for publication: 13.08.2018

Otrzymano: 16.05.2018 r.

Zaakceptowano do publikacji: $13.08 .2018 \mathrm{r}$.

\section{Address for correspondence:}

Adres do korespondencji:

dr hab. n. med. Dariusz Plicner,

KSS im. Jana Pawła II, ul. Prądnicka 80, 31-202 Kraków, tel. 501499 845, (12) 61430 75, fax. (12) 4233900 , e-mail: plicner.dariusz@gmail.com 